\title{
ON THE DIALOGUE OF VALUES IN SACRAL ARCHITECTURE AND ART OF THE EAST AND WEST
}

\author{
Jerzy Uścinowicz \\ Dept of Public Utility Architecture, Bialystok University of Technology, \\ 15-893 Bialystok, ul. Grunwaldzka 11/15, Poland
}

Submitted 01062007

\begin{abstract}
The author reviews the past and present examples of the diffusion of values in the Christian Churches, i.e., of the Eastern (Orthodox and Unite) and West (Roman Catholic and Protestant). They are portrayed through mutual conversion of temples, incorporation of traditional orthodox iconography in contemporary Roman Catholic churches as well as by adaptation of historic temples for their mutual ecumenical use. The values give testimony to the synthesis of art of both Christian Churches as well as to the return to their ecclesial unity. Apart from a retrospective look at contemporary, post-war buildings of this type the authors' realizations are also introduced.

These examples are representative for the architecture of cultural borderland which attempts to synthesize both the Western and Eastern Christian art.

Keywords: architecture, temple, sacrum, conversion, adaptation, synthesis, borderland.
\end{abstract}

\section{Introduction. Between a global and a local culture}

For centuries, mankind has lived in communities which grew and matured in different places of the Earth. There have been national, tribal and nomadic communities or even geographically isolated communities. This was so up to the end of the 20th century when the Earth became a global village.1.

Cultures growing from specific environmental conditions had and still have characteristic traits which distinguish them against the background of other communities. Indigenous ethnic cultures conditioned by the environment of their owners were a barrier which balanced and mitigated man's negative impact on nature and vice-versa. Therefore, it was possible to maintain a certain ecological equilibrium.

Native culture is the local economy, adjusted to the conditions of the environment as well as local economics, evenly managing the inflow of produced goods. But also, these are the local religious beliefs. This also comprises architecture which, as a component of culture, is for all the aspects of man's life an external spatial casing, an organization, fulfillment of values in achieving beauty, architecture which at some occasions separately and sometimes to a greater or lesser density and order, in a different relationship to the environment found in nature, contributed to the creation of settlements, villages and towns and indirect spatial works which grew from them. Thus, the framework was created for cultures built naturally, without stress in relationships with nature and, as may be said, in agreement with God's idea and His inspiration.

On the other hand, however, man has always headed in the direction of a certain global form of ecumenism. The history of civilization shows that, throughout time, man has gradually liberated himself from the influence of the laws of nature, thanks to his free will as well as such extraordinary talents as speech or abstract thinking. Man's path toward independence may be scrutinized on the basis of experiences provided by the history of civilization and recognized by discoveries, inventions, scientific theories. We have had the Age of Bronze, Iron, Steam, Steel, and Plastic and finally we have the Age of Computers. Thanks to them, information immediately spreads around the world. The Internet, satellite broadcasts, electronic pictures and sound transmissions from afar, this is the standard of contemporary world. It seems that everything is close to us, at arm's reach. While remaining in our family house we can virtually be in New York, Rome, Jerusalem or ancient Constantinople. 
Thus, despite a certain isolation and being permanently ingrained in his father's natural environment, marked by divers products of culture, man inevitably heads in the direction of communal life, from separate tribes through communities, association of communities towards some form of global human family. It seems that this is the normal manner. Natural evolution makes happen that people from different countries, of different races and speaking different languages come close to one another. Boarders are becoming blurred, and everything is becoming less distant, more familiar, friendly and "one of ours".

This is a positive phenomenon, but does not it bring about some unsettling occurrences on Earth? Because in this informational madness, immersed in a virtual world in which everything is immediately and everywhere accessible, is it not that we know more about what is happening in the distant culture of Australian aborigines than about the place in which we are rooted?

Thus, is it possible to ask whether the current indistinctness of borders is desirable Does it make sense? Does it show us the way in the right direction?

The answer to this question is not unequivocal. We are dealing with the dichotomical division of this world, in each area of life, from the very beginning. Division and unification are an archetype of life on the Earth. Differentiation, division, polarization and exclusion and, on the other hand, opposite processes, i.e., contact, rapprochement, assemblage and continuous dialogue, exchange and contact are indispensable to our existence. For ages, since the beginning, this has been accompanying in different forms of this life and probably in all areas. Is it possible that contemporarily, this inevitability of the process be properly steered and not threaten and ultimately destroy, that which is the authentic value of human achievements?

To answer this question we must recall tradition. It can help us not only in identifying historical facts of how it was but to properly diagnose and forecast, to know how it is to be in future.

Therefore, lets ponder about how it was in the past and how is it today. Is not this separation of cultures and diversity of values which, at all costs, must be protected while simultaneously looking for mutual relations and associations of this independence and perhaps even mutual enrichment and perfection? Whether popularization of ostentatious and universal monoliths is not the greatest, global, threat to the present?

Let's relocate with this dialogue planned by us amid cultures, nations and religions onto grounds which may be the model of our analytical operations, into the area of sacral architecture in which these issues may be well reinforced.

Because the Church, especially the Christian Church, was and is the most "global" institution in the world. It wants to be loyal to the command of Christ who ordered his Apostles, "Go ye into all the world, and preach the gospel to every creature" (Mark 16:15). This declaration of the Gospel was carried out in numerous ways for the Acts of the Apostles tell us that, on the Day of Pentecost, all of them were filled with the Holy Spirit "... and they began speaking different languages ..." (Acts of the Apostles 2:1-13) [1]. Therefore, let us reflect upon the following isusues.

- Whether these divisions within the Christian Church as well as the side by side existence of numerous other churches, religions and cults, confessions and rites, beliefs and types of spirituality on one Earth are not correct and natural ?

- Is the exclusiveness of all Christian Churches, their dogmatic, ecclesiastic and ritual differences, differences in the comprehension of the Church's preeminence and Churches in all of Christianity and Christianity in relationship to other religions, differences in characters and nature interfere with the dialogue, their interrelations and mutual enrichment, in the real exchange of values?

We are recalling just a few examples which, should they not respond directly to these questions, will at least, lead us to them, will identify the problem and will heighten its meaning. Let's do it on the example of Poland which seems to be an appropriate example.

\section{Between the east and west. Art of the cultural borderland}

As we know, Poland is located within a cultural, religious and national borderland. In the historical as well as in the contemporary finally defined territorial borders, it is situated on a line which runs through from Scandinavia to the Balkans, a line which divides Europe into that of the Latin culture, Western catholic and the Byzantine Greco-Slavic culture. In the past, prior to the Partition of Poland, this line was positioned in the exact center of the country. The geographic majority of Poland and the Grand Duchy of Lithuania was located on the Byzantium side. Now, following the Second World War, only a small part of eastern Poland remains on the former Russian - Byzantium side. 


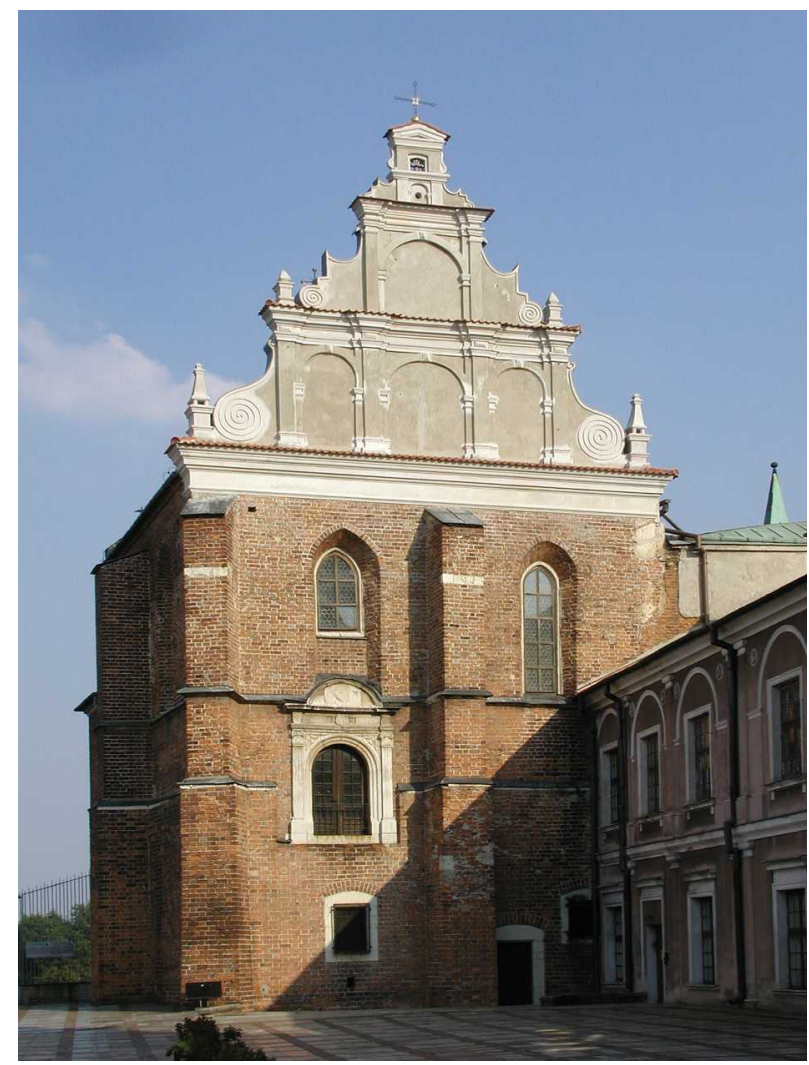

Fig 1

The existence of the borderland of two cultures, two kinds of spirituality, is an extremely interesting phenomenon. It stimulates the mind and imagination, provokes to all kinds of philosophic, theological and cultural reflections. It is an inspiring occurrence and is picturesque. Nevertheless, sometimes it is also dangerous, abounding in old conflicts and prejudices. It was so in Poland and Russia, in Hungary and Rumania. It is so, even nowadays, in the Balkans. The separation of the two Churches - Western and Eastern - became a painful, permanent turning point in the history of Christianity. Even now, certain former prejudices and phobias come to the surface. Today, however, we are lucky enough that the worshipers of these two Churches coexist in relative tranquility. In addition, perhaps under the influence of the ecumenical movement or for other reasons, there currently exists a vibrant mutual interest. We are observing an initial influx of ideas and numerous forms of spirituality. Sometimes, mutual contacts are reviving. It is possible to say, and today this is a very positive phenomenon, that this is not a simple meeting and a dialogue, but rather a transmission, exchange of values and mutual enrichment. It is, perhaps, an attempt to synthesize.

It must be acknowledged that this is not a new historical occurrence, for such a diffusion of values already

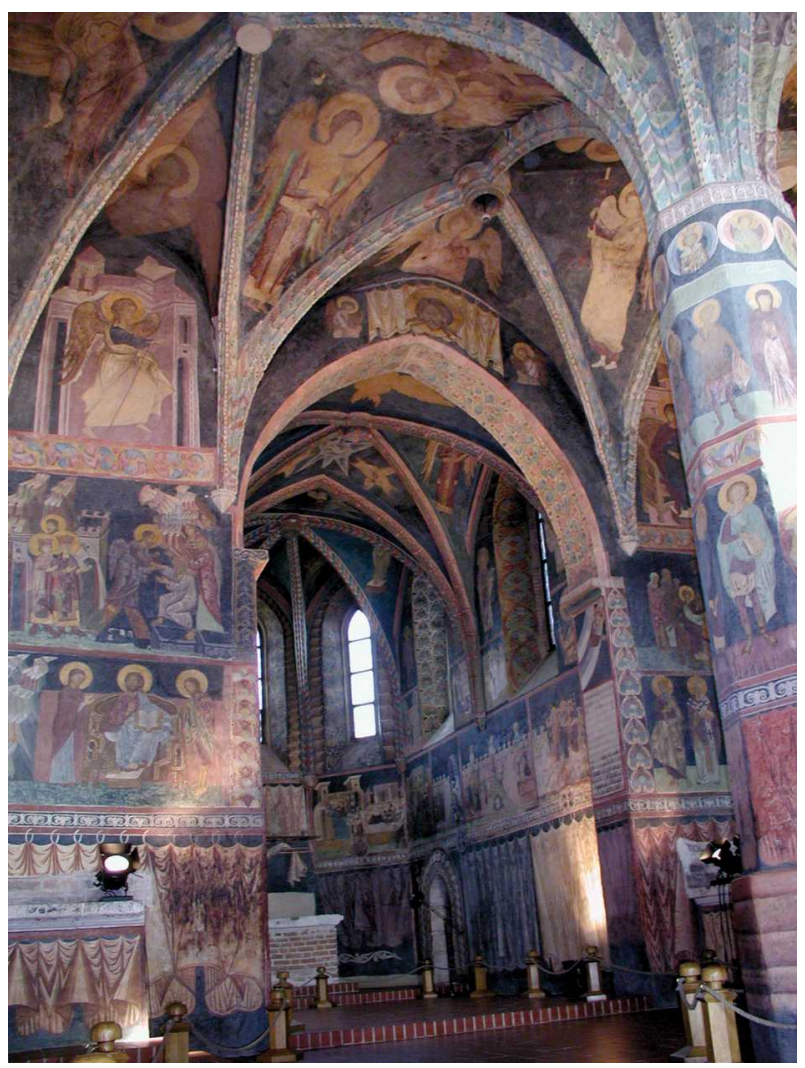

Fig 2

existed from at least the 15th century. This is exemplified by Ruthenian and Byzantine wall paintings in gothic churches during the age of the first Jagellonian Dynasty or the opposite, Gothic influence on the architecture of the Lithuanian and Ukrainian Orthodox Churches in the 14th-16th centuries. It is the diffusion of Poland's musical culture into the Ukraine and later on, all of Ruthenia which, for many centuries, developed the style of liturgical singing in this part of the Orthodox Church. It is the influence of scholastic theology on Kiev and indirectly on Moscow, which brought attempts of ecclesiastic synthesis, undertaken by the Metropolitan Peter Mohyła in the 17th century, and finally there is diffusion of Renaissance and Baroque elements into construction and sacral art [2].

These are but a few examples. To justly appreciate the rank of this phenomenon they are worthy remembering, at least the most spectacular ones, taken from architecture and painting.

The first one is the Church of the Holy Trinity, also called the Castle Chapel, built in 1326, which served as the Royal Chapel (Fig 1). Interior walls of this Gothic Western sanctuary endowed by King Władysław Jagiello, were covered by Ruthenian painters with extraordinary 15th century wall paintings executed according to the 


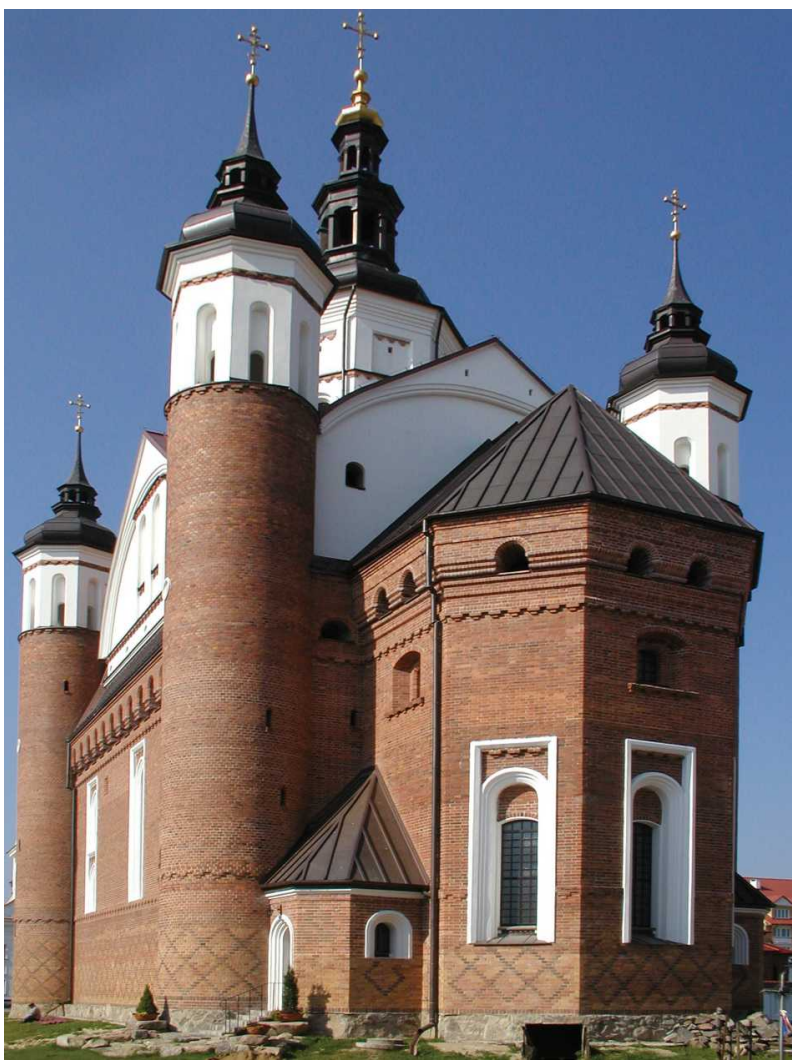

Fig 3

Byzantine canon (Fig 2). Almost totally preserved, this is undoubtedly, one of the most beautiful examples of this kind of paintings to be found in Poland. Its uniqueness and beauty result from a diffusion of values, from the harmony of a merger of Gothic architecture and the art of icons.

The second one is the Orthodox Church of the Annunciation of the Holy Virgin Mary in Supraśl, erected in 1503-1511. This is a phenomenon not only in the history of Polish but also European architecture, however, nonhomogeneous but unusually original (Fig 3). This is a shrine in which a three-part liturgical structure characteristic of the Orthodox Church of RuthenianByzantine origin has been attired, as though in Gothic costume [3]. The external shell is the Western Church and the interior is a classical cross and dome Orthodox Church, a nine field type quincunks (Fig 4).

It must be admitted that, in the past, mutual contacts and attempts to exchange values were definitely limited. Both churches, Roman Catholic and Orthodox, were structures of a rather closed character. They preserved their dogmatic and doctrinal integrity. They also protected themselves against inflow of spiritual vales, even in the area of cult or on the level of art. Nevertheless, such an inflow occurred, even though this took place

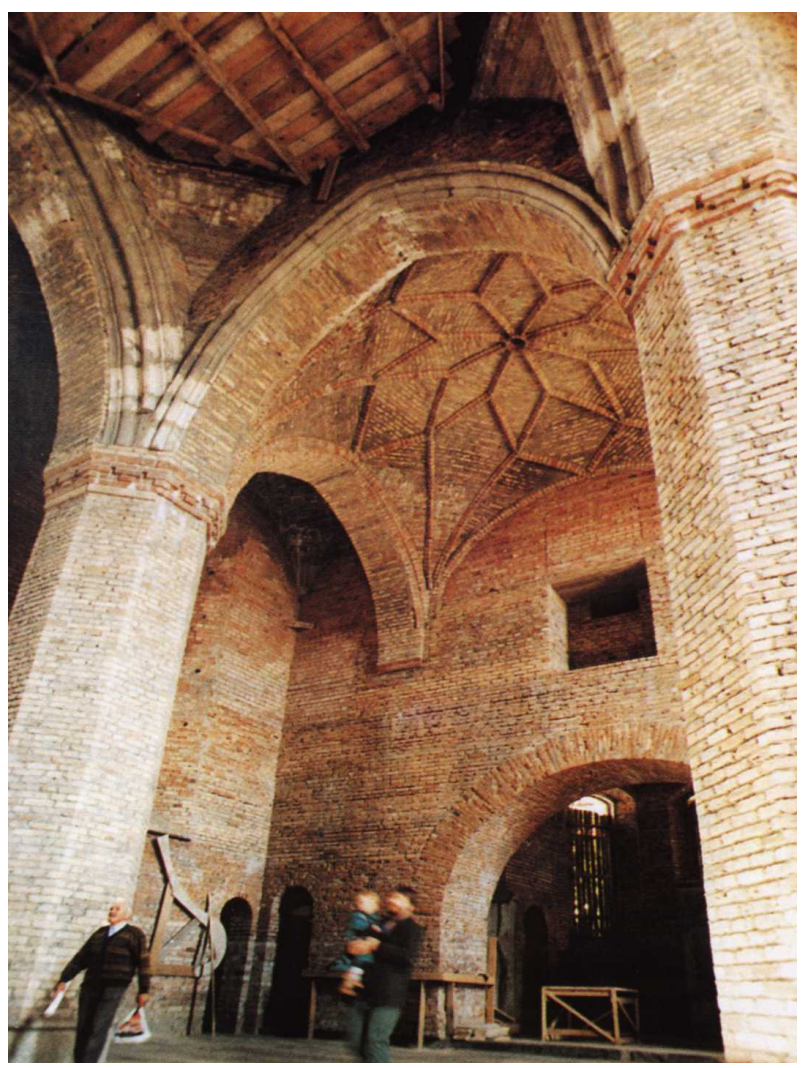

Fig 4

against the will of these Churches. This was a spontaneous experience, and no barriers, orders or prohibition would do any good.

Today, throughout the world, especially in the area where Christian religions predominate, the situation is somewhat different. Dogmatic and ideological borders have receded into the background. In more culturally and spiritually advanced surroundings, especially in the arts, an authentic and sometimes very intensive exchange of cultural goods is taking place.

\section{Interconfessional conversions}

Orthodox and Unite churches, as well as Roman Catholic and Evangelic Churches, are the contemporary examples of such an exchange of values.

One of the first and most important is the Cathedral of the Birth of the Holy Mother of God in Wrocław, formerly the Gothic church of St Barbara. Initially, it was a Roman Catholic church, later on an Evangelic church and since 1971, it is an Orthodox shrine (Fig 5).

Jerzy Nowosielski and Adam Stalony-Dobrzański are the artists responsible for the new decor of the Orthodox church. Eschatology occupies the primary place in the ideological program of the shrine. This is 


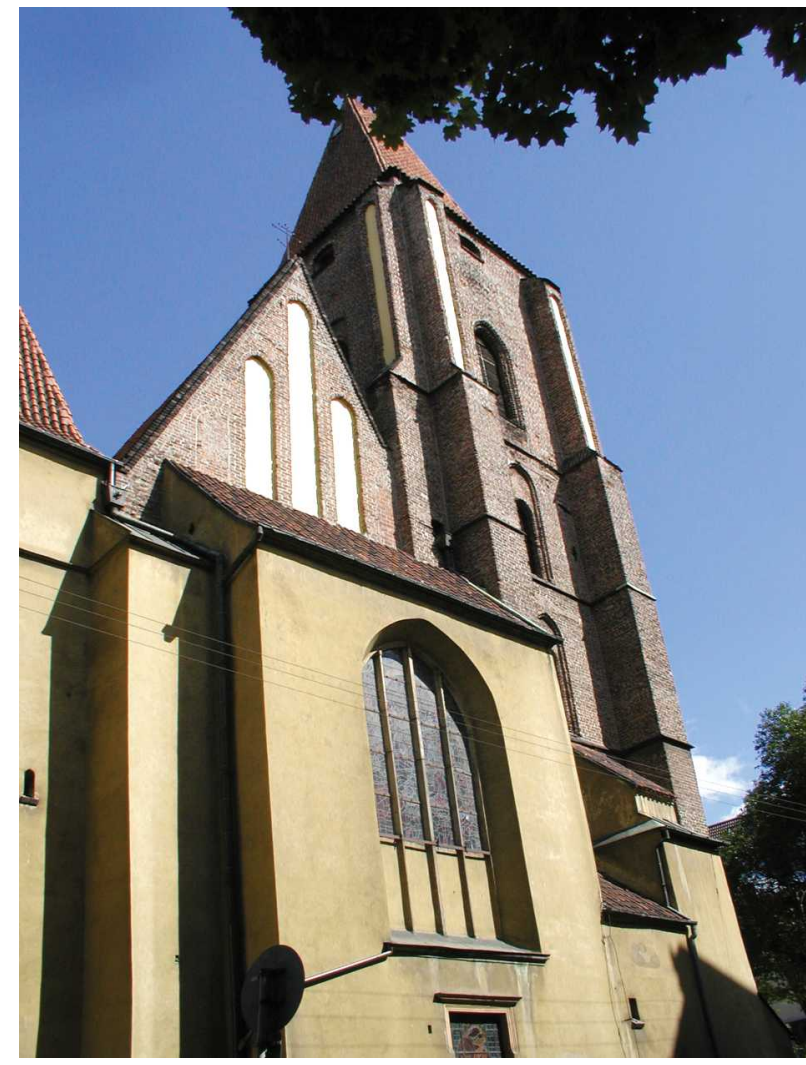

Fig 5

mainly shown by the introduction, in the interior of the shrine, of the iconostasis with a row of icons showing, as it was in the former main Gothic alter of the church, the history of the life of Christ on the Earth [4].

The iconostasis fastens together, upwards, the Crucifixion [5]. This cross joins the iconostasis program with the wall paintings on the chancel vault and closes off the entire axis composition (Fig 6). This relates to Italian paintings of the 13th century, that is paintings from the time of the separation of the Byzantine and Latin traditions, and at the same time attempts to bring closer and acquaint both traditions with each other. The iconostasis is of an almost open work construction and because of this constraint, is linked to a relatively deep chancel as well as the church nave. It is not a barrier but a passage way, a window onto the "celestial world" shown in the sanctuary. It precisely designates the center of the shrine. Very large, suspended low panikadylion - choros reinforced its position. In the interior and the central character of the space in this shrine, as if it were to substitute here the traditionally located dome with the Christ Pantokrator [6]. The application form of the icons on the vault and the rhythm and symmetry of the vaults supports this concentricity, as if to balance the longitudinal linear disposition of the former church (Fig 7).

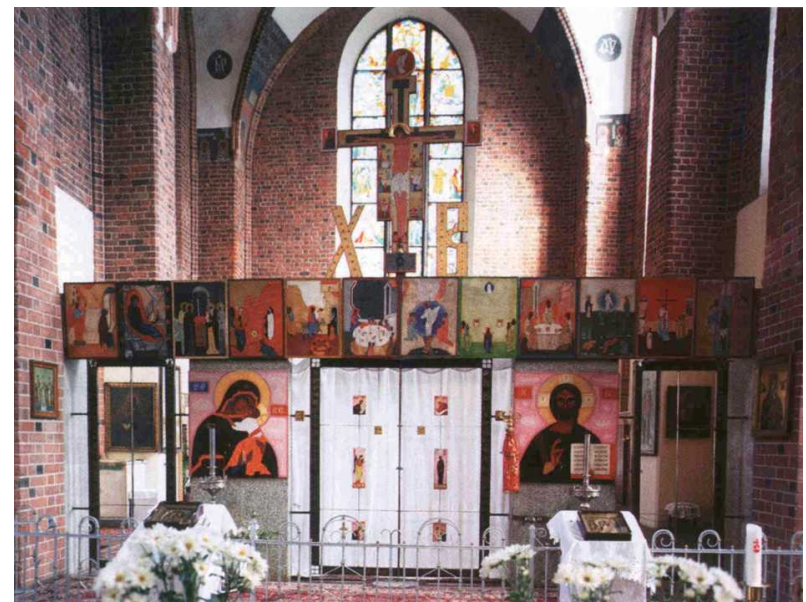

Fig 6

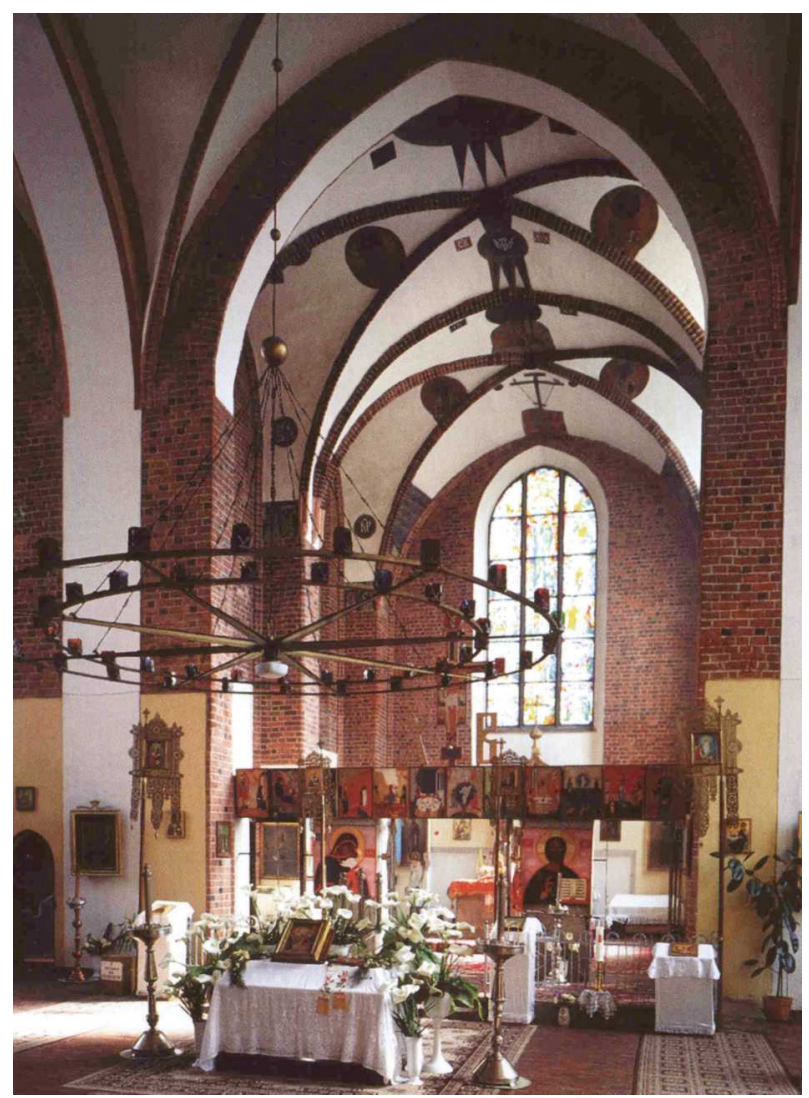

Fig 7

Adopted from the West and applied here, convention of iconic illustrations are the stained glass windows, above all a magnificent stained glass depiction of the scene of the Final Judgment which is situated in the window of the western wall [7].

A subsequent, equally interesting and original example is the former church in Jelenia Góra. On the outside, it remains a small, typical Baroque church. 


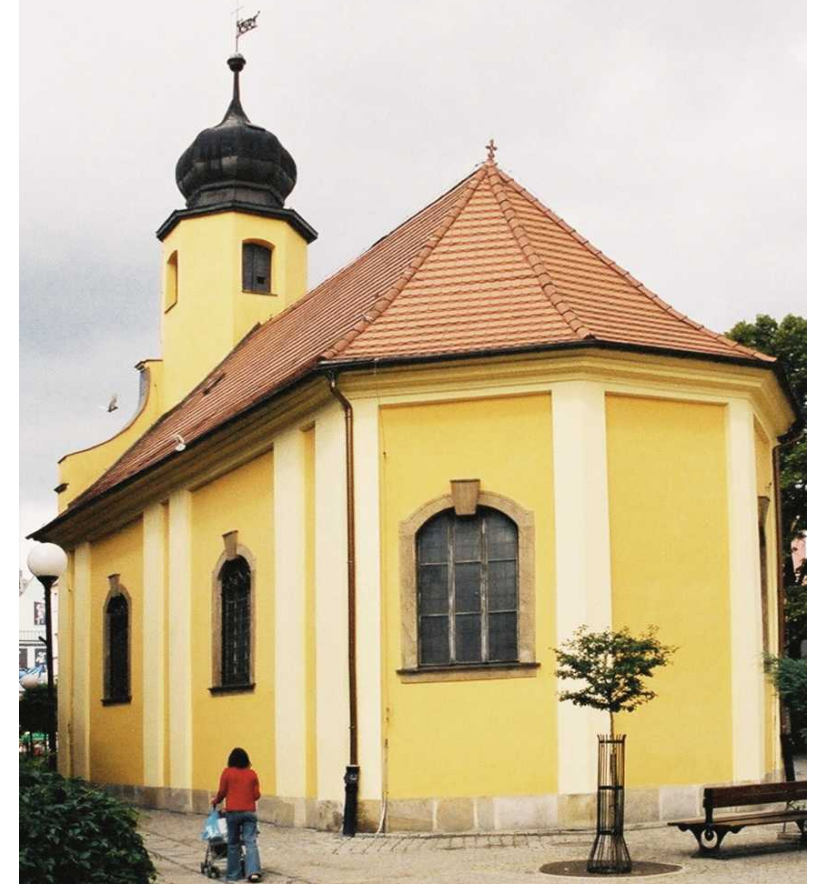

Fig 8

Inside, it is the Orthodox church of Apostles Peter and Paul.

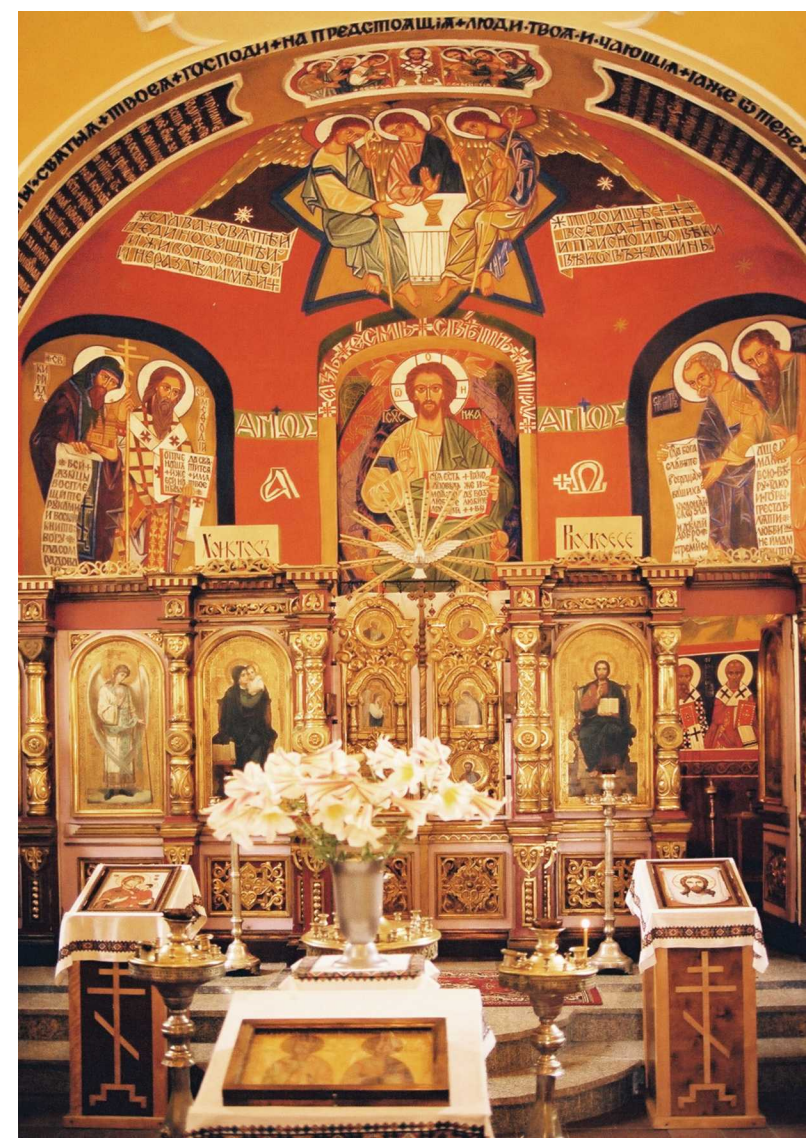

Fig 9
The earlier chapel, built in 1738 , served Roman Catholics till 1925 when, in the face of economic crisis and a decreasing number of worshipers, a decision was made to return it to the town authorities. The Baroque fittings were moved to other churches. Its interior was initially converted into an exhibition hall and subsequently into a military museum. After the end of the Second World War, when Jelenia Góra found itself within Poland's borders, the small church dedicated to Holiest Virgin Mary was, in 1948, handed over to the Jelenia Góra Orthodox Parish which was organized a year before [7]. Today, the Orthodox church is a modest one-nave church built in the Baroque style. The tower is crowned with a characteristic for the Baroque onion-shaped metal dome, referring in its form to the typical simplified multi-elemental Orthodox church dome (Fig 8).

The interior of the chancel of today's Orthodox church has been decorated with beautiful frescos also painted by Adam Stalony-Dobrzański and Jerzy Nowosielski. The frescos, even though directly referring to the Byzantine style, have an original individual character. Their central figure is the Christ Pantokrator. On both his sides saints are situated (Fig 9). The small

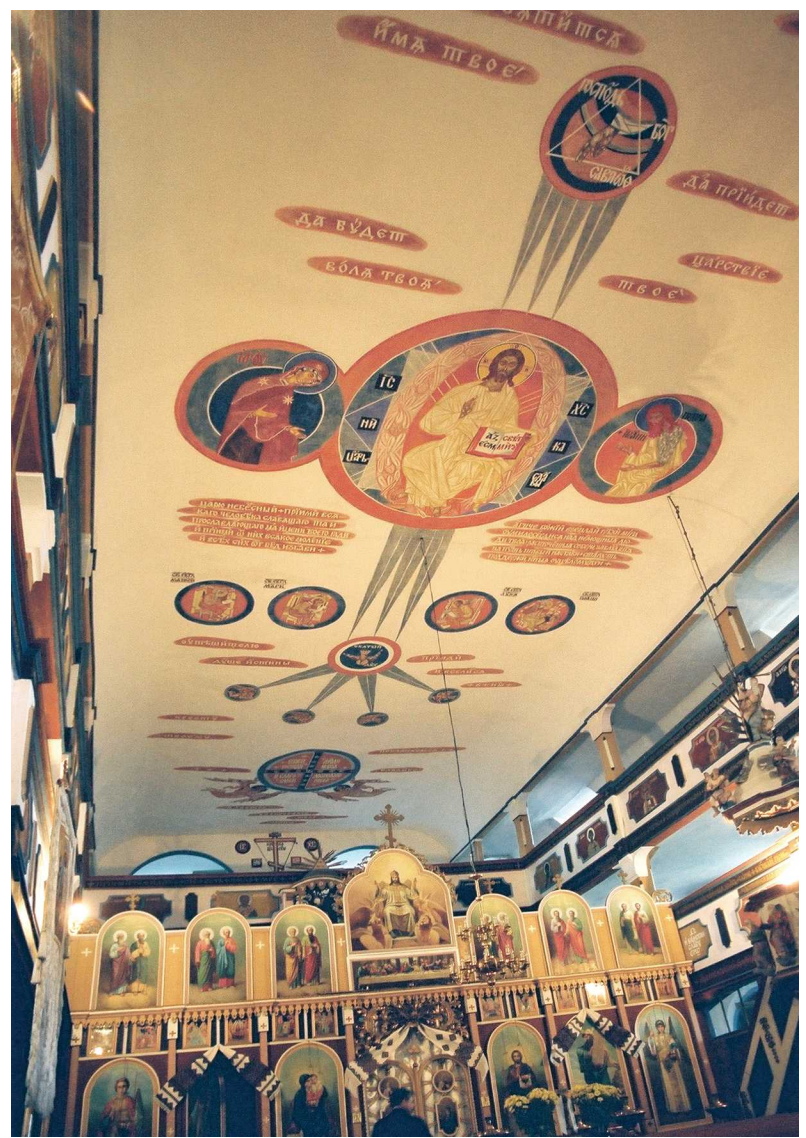

Fig 10 


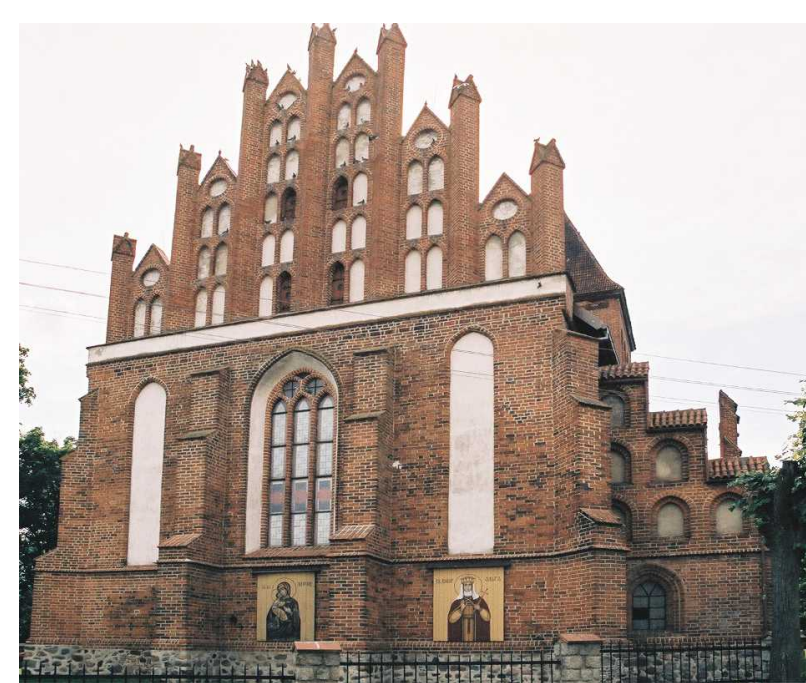

Fig 11

iconostasis with royal doors and icons gathered in the church were brought from Orthodox churches in the Lublin Voivodeship which had been destroyed during the War. They all give testimony to history as well as are a carrier of tradition handed over to the new inhabitants of this land.

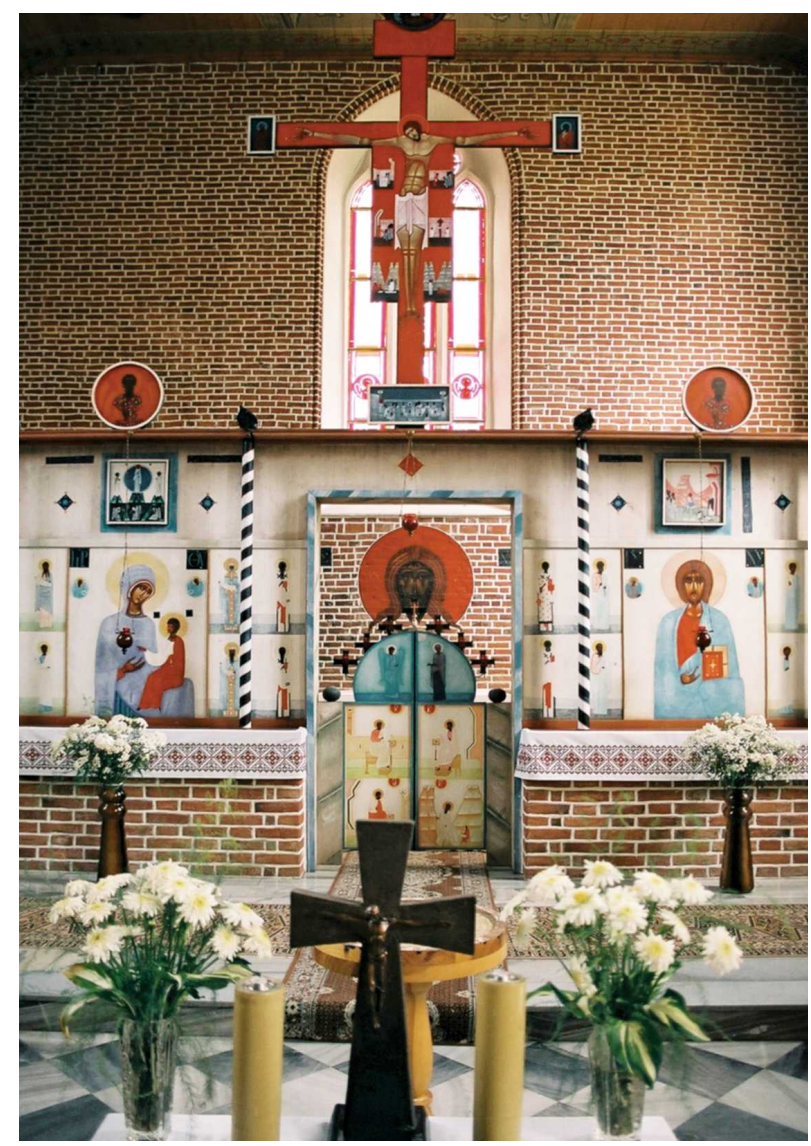

Fig 12

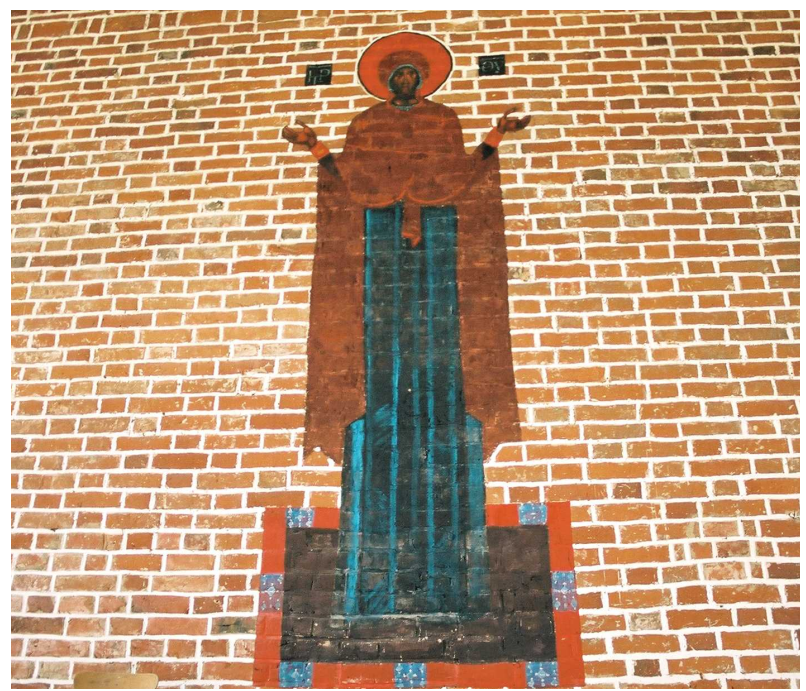

Fig 13

The discussed examples of the conversion of shrines may be supplemented by subsequent important sites located in such Polish geographic regions as Lower Silesia, Western Pomerania and Warmia and Masuria, shrines adopted by the Orthodox and Unite populations displaced from their homeland. The Silesian Orthodox church in Przemków is a good example of this, where as is typical for post-Evangelical churches, a basilica-like interior with a double leveled empors, a magnificent Orthodox iconography had been realized (Fig 10). Such is also the case with the post-Evangelic, Western Gothic church in Górowo Iławeckie (Fig 11). This time Nowosielski created a unique shrine for the GrecoCatholic population. He achieved it in an unusually delicate manner, cautiously, by means of iconostasis with a huge crowing cross, reminiscent of the ancient Cross of St Francis (Fig 12) or by magnificent icons painted on walls of red gothic bricks (Fig 13). It is worthy reminding that this cross, appearing very often in Catholic and Orthodox churches is an extraordinary unifying force of both traditions. But we will discuss this at the end of our deliberations.

\section{Incorporations}

Perhaps the first example of this mutual enrichment and diffusion of values in the Roman-Catholic Church is the shrine situated in the Jelonki district of Warsaw. The most interesting of the applied solutions are polychromes, painted on red bricks as is in Górowo Iławeckie (Fig 14). With quite expressive and even somewhat irritating tectonics of the church's interiors, additionally enriched by semi-stained walls of the side naves and 


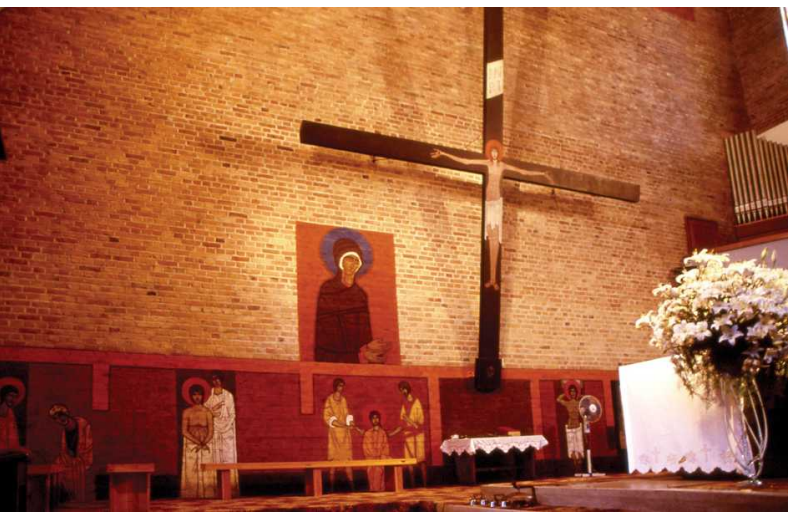

Fig 14

exposed construction of the vaults, these paintings are distinctly soothing and contemplative (Fig 15). They simply decorate the church and are an extra beautifying element of limited significance. They are, above all, transferred from the East, theology of expression. They are theology.

The most beautiful, however not finished, paintings are the polychromes in the church in the Upper Silesian town of Tychy. Its intriguing, modern architecture, designed by the architect Stanisław Niemczyk, comprises something from an archaic desert tent, perhaps even based on the Old Testament's Tent of Meeting (Fig 16). It also has in it something of an old traditional village church with a spread out wide roof as the Maforion of Caretaker Mother of God. Surrounding, almost reaching the ground saturdays, numerous large and small walls and details saturated with symbols already forecast the atmosphere of the uni-spatial interiors. They are built by huge load-bearing girders, with a cross-vaulted vestibule joining at the crowing achievement creating a classic, as was in Byzantium, centrally located dome space (Fig 17). It is not fully a dome space for, above all, above it there is no dome but only a lantern and the concentricity of internal space. The hierarchy and, above all, the manner in which light is introduced at the top into its center create such an impression. The vertical axis, reinforced by a glass opening in the direction of the lower chapelvault, at the bottom of the main alter, emphasizes this cosmic vision of union with God. This is, perhaps, most developed in the peripheral Byzantine shrines as well as Moldovan and Trans-Caucasian shrines.

This vision was accessed by Nowosielski. He designed his own program, in accordance with the summons of the church of the Holy Ghost, defined in the form of icons. This kind of creation is to be found in the entire iconographic structure of the wood paneled ceiling, in the figures of saints and flickering red flames above their

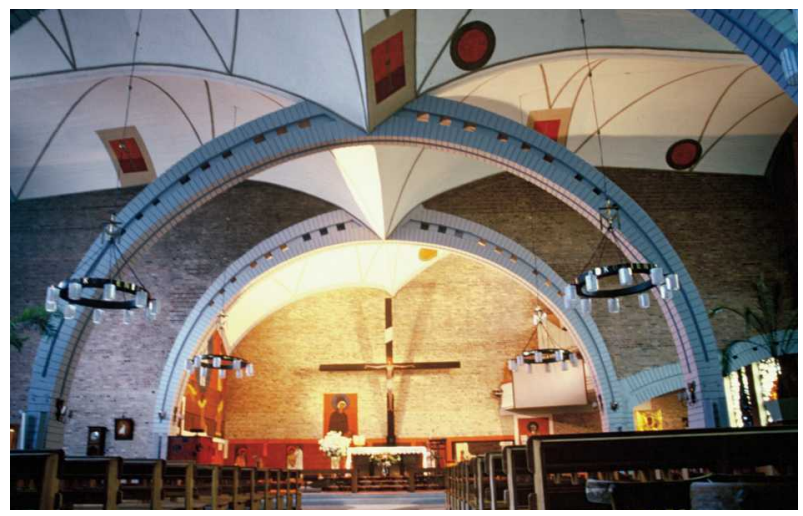

Fig 15

heads. It is visible in the blue ribbon of the flame accenting the main axis, as if cutting through the line of the horizon, from the Holy Spirits' doing, here symbolically recalled in the form of a Turtle Dove [8].

On the axis, on the alcove of the ceiling, as formerly on the indestructible wall of the altar abse, Nowosielski placed a huge half-figure of the praying Theotokos Oranta (Fig 18), different here than in Byzantium because without the Infant. She is accompanied by the Old Testament Patriarchs, Prophets and Kings, further on, in the semi-transept, by the Holy Apostles, Martyrs, Fathers and Doctors of the Church not divided, Eastern and Western Orthodox. On the side axis of this transept are two scenes, i.e. Transfiguration and Crucifixion.

At its intrados, under the skylight of the lantern is the scene Deesis - the Holy Mother, John the Baptist and the veraikon scarf between them. Across from them stands Archangel Michael, protecting access. On the side of the altar etimasia - is an empty throne awaiting Paruzja.

Next, of great importance to us, is the Church of the Divine Providence in Wesoła, a suburb of Warsaw. This church was erected in 1938 in the Neo-Roman style (Fig 19). Its interior was decorated as late as 1975-1976. It is a masterpiece of iconographic and architectural art, from the beginning to the end carried out by Nowosielski.

The interior of this church is a small white hall with a closing abse (Fig 20). With a cross centrally placed on the axis and the Madonna posing as the Oranta without the Sign, as was the case in Byzantium, as is in the Tychy church. Here, following numerous reflections, however not without the burden of undertaking this decision Christ, who is usually placed with the Madonna as the Blacherniotissa, is replaced by the Crucifixion in an interesting transposition of the St Francis of Assisi cross. 


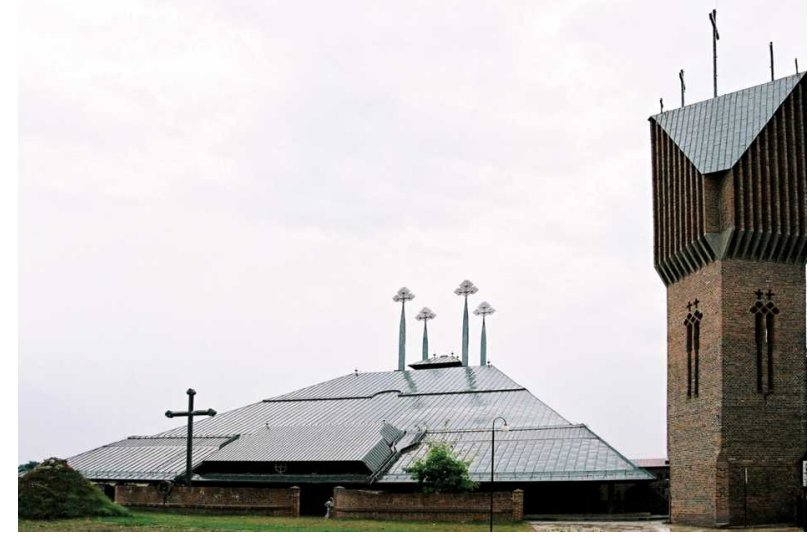

Fig 16

However, they are still together by the spatial positioning of the cross and the Holy Mother (Fig 21).

The magnificent Way of the Cross was painted on canvas in a white frame, as bas-relief, brown-black inside the defensive wall of Jerusalem and not in the open air scenes of Via Dolorosa. This is an outstanding piece of art. In the altar section there is an interesting spatial transposition of the altar templon, a living copy from the first ten centuries, from the Justinian Basilica of Hagia Sophia. The architecture is superbly complemented by the iconography on the walls and abstract stained glass windows. This is a unique example of the total realization of the interior of a Latin church in the Eastern Christian character.

\section{Last transpositions}

Another example of a contemporary shrine built in the beginning of the ' 90 s and designed by the architect Jerzy Uścinowicz is the Orthodox church of the Resurrection located in the Słoneczny Stok district of Białystok (Fig 22). This shrine retains the traditional Orthodox symbolic structure. It is, however, an attempt to currently reinterpret it taking under consideration the particular historic and cultural context of the so-called borderland region. The main themes link the Orthodox shrine with numerous fortified shrines built in the Byzantine-Gothic style, such as the aforementioned Orthodox churches in Supraśl, Synkowicze, Małomożejkowo or Nowogródek. Indirect stylistic links are visible, however limited to the external form. They are structuralism of composition, "cristallinity", application of the typical Gothic pinnacle, buttress, gargoyle or the solutions of the entrance gables (Fig 23).

The Shrine has a central composition, built on the geometry of mutually penetrating figures of an octagon and a Greek cross (Fig 24). Its external form emphasi-

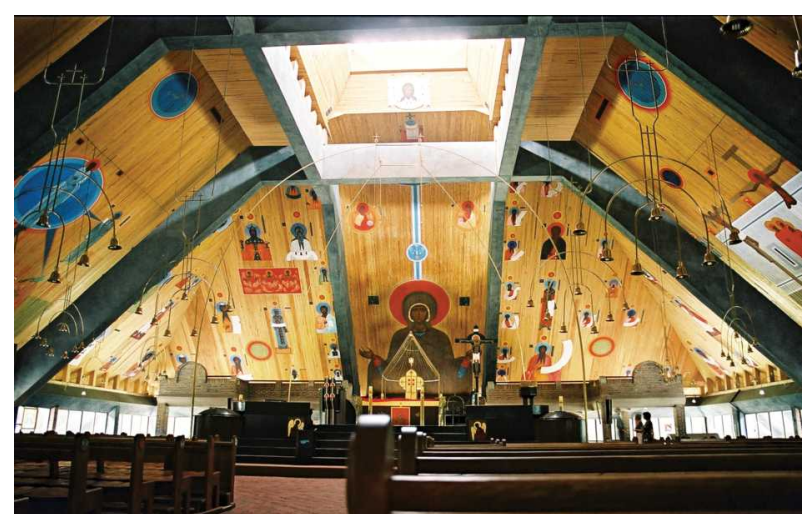

Fig 17

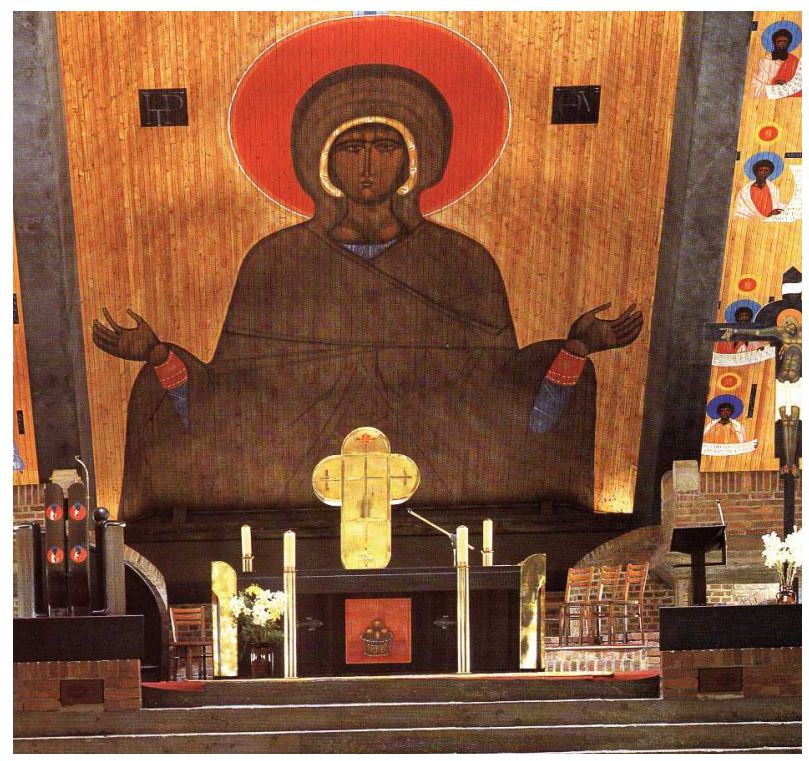

Fig 18

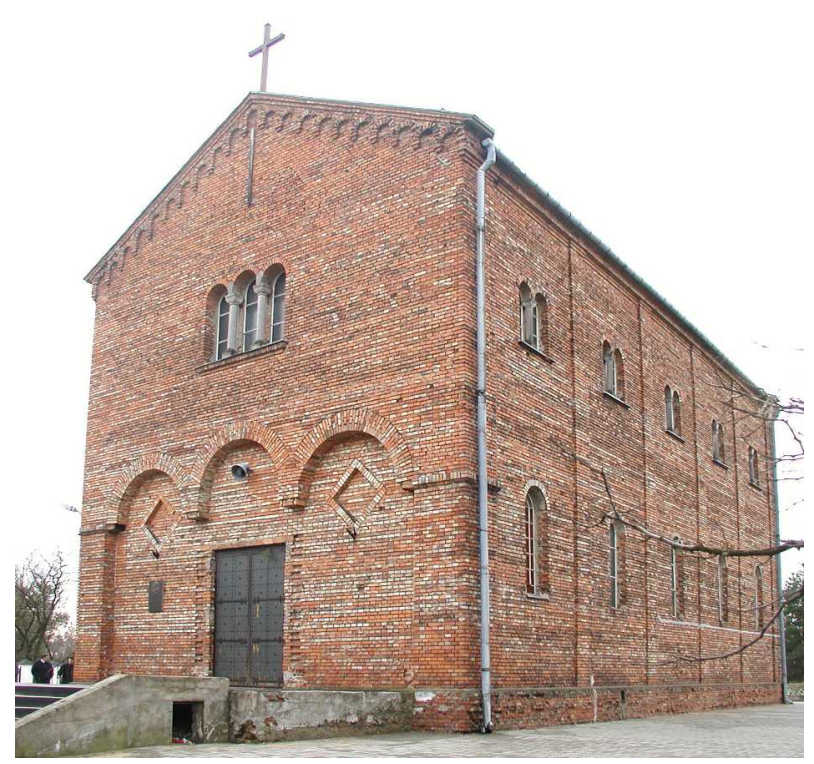

Fig 19 

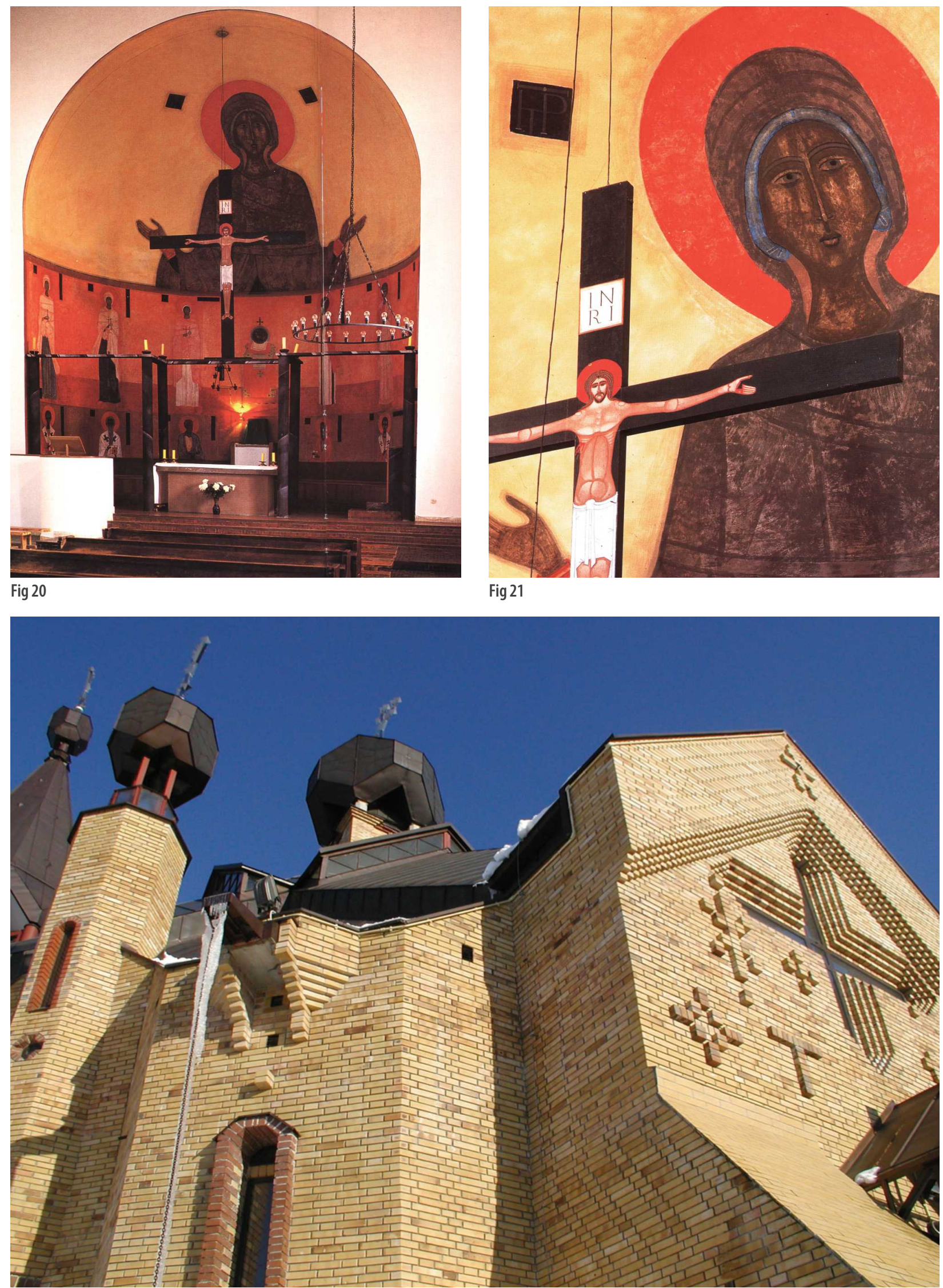

Fig 22 


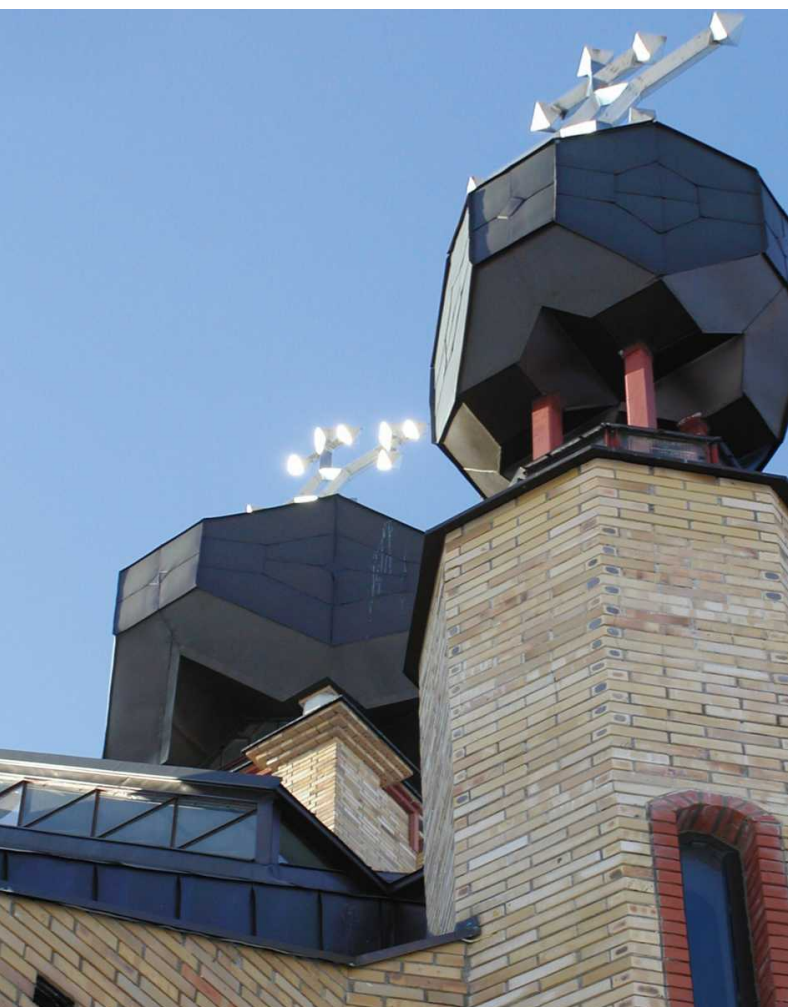

Fig 23

zes the Summons by the symbols of the Holy Sepulcher and the Resurrection, i.e., the geometry of an octagon as an eschatological figure, forms of buttresses as rocks removed from the Sepulcher, forms of the surrounding escarpment, the foundation made of erratic rocks or the eight poles. Situated on a hill, the shrine emphasizes the expression of form and its exuberance. The use of crystalline forms in the domes refers directly to the Revelation of St John the Divine and his description of New Jerusalem, “down from God out of heaven, clear as crystal" [10].

And, finally, the last work realized by Nowosielski. It is the cross in the Church of the Dominican Fathers in the Służew district of Warsaw or rather an Orthodox icon of the Crucifixion, which has become the central icon of the chancel, organizing and concentrating on itself the entire liturgical time and space (Fig 25). It is worth noting that the notion of the Crucified Christ was the most circulated type of medieval Italian icon. Huge, supplemented by the figure of the Holy Mother, St John the Theologist and scenes of the Passion, it was placed on every iconostasis of the Italian Church. The Franciscan cross is the Italian type of Crucifixion from top of the iconostasis, a majestic magnificent icon which became the subject of contemplation of St Francis. It also became

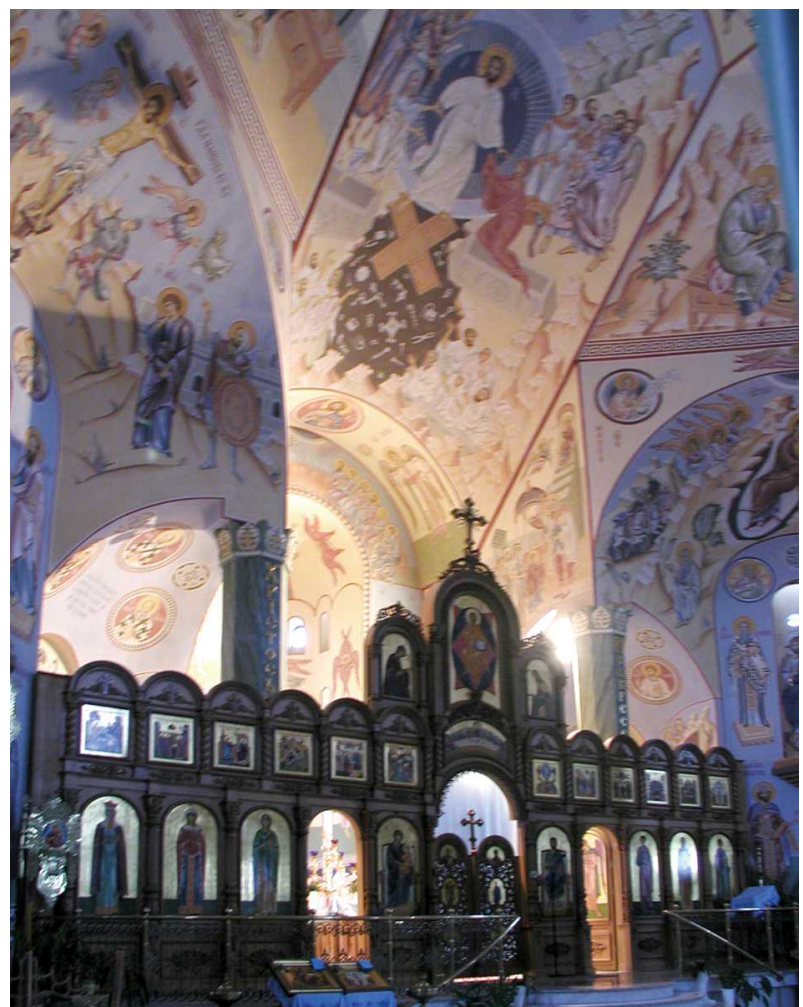

Fig 24

a splendid, symbolic spiritual unifying force between the East and West. Such, it remains till now [11].

\section{Conclusion}

The architectural examples of shrines of both Christian Churches, those of the East and West, presented here are but an introduction to deliberations on their mutual dialogue, on a serious discourse on the diversity and respect for distinctness and multitude. In the Greek language, dialegein means to converse which, in the general meaning of this word, is an exchange of thought. On numerous occasions we have become accustomed to the fact that, in the area of dialogue between religions and cultures of different nations, most commonly used is the term "meeting" which, in the proper understanding of the word, is not a dialogue but indispensable conditions for its occurrence.

In sacral art of both Churches, in such objects, with their diversity and similarities, autonomy and at the same time, unification of their diverse components, the Christian world is returning, somewhat, to its initial unity. This unity is already being realized, taking place directly, openly. It is not only a meeting and not only a dialogue. It is something more. In this 
attempt at synthesis, art of both Churches reaches its sense and meets its objective. It fulfills itself in what it was created for. It is becoming the art of one Church, no longer divided.

Therefore, is it not the truth, as Fiodor Dostojewski superbly said that art will save the world. Today, one may add, however shyly, the entire world. ${ }^{*}$

\section{References}

1. Biblia, to jest, Pismo Święte Starego i Nowego Testamentu $z$ Apokryfami (nowy przekład z jęz. hebrajskich i greckiego), Brytyjskie i Zagraniczne Towarzystwo Biblijne, Warszawa, 1990.

2. PODGÓRZEC, Z. Mój Chrystus. Rozmowy z Jerzym Nowosielskim. Wydawnictwo Łuk, Białystok, 1993, p. 89-97.

3. ШЧАКАЦІХІН, М. Нарысы з гісторы беларускага мастацтва. Крывіцкае (Вялікалітоусскае) Навуковае Таварыства Пранціша Скарыны, Нью Ёрк, 1970, p. 259-260; JANKIEWICZENIE, A. Wschodni obszar występowania gotyku i niektóre specyficzne cechy litewskiej architektury XV-XVI wieku. W: Kwartalnik Arch. i Urban., T. XIX, Vol 3, Warszawa, 1974, p. 232-242; Kwartalnik Architektury $i$ Urbanistyki, T. XI, Vol. 4, Warszawa, 1966, p. 360-364.

4. CZECHOWICZ, B. Ecclesia Sanctae Barbarae. Katedra Prawosławna Narodzenia Przenajświętszej Bogarodzicy we Wrocławiu. Editor Igor Rydzanicz, Arboretum. Wrocław, 1996, p. 20-24.

5. NOWOSIELSKI, J. Mistagogia malowanego wyobrażenia Ukrzyżowania Pańskiego. Znak, 16/1964, Nr. 126.

6. UŚCINOWICZ, J. Kopuła jako conditio sine qua non w świątyni ortodoksyjnej. Budownictwo Sakralne $i$ Monumentalne'1998. Dział Wydawnictw i Poligrafii Politechniki Białostockiej, Białystok, 1998, p. 359-360.

7. UŚCINOWICZ, J. Symbol, archetyp, struktura, Hermeneutyka tradycji $w$ architekturze światyni ortodoksyjnej. PB, Białystok, 1997.

8. Archiwum Akt Nowych, UdSW, sygn. 13/30, Pismo UdSW do Prezydium WRN we Wrocławiu z dnia 25 lutego 1952.

9. PORĘBSKI, M. Nowosielski. Wydawnictwo Literackie, Kraków, p. 98-113.

10. UŚCINOWICZ, J. Wybrane problemy z rzeczywistości sakralnej - kryterium tradycji w architekturze wschodniego kościoła ortodoksyjnego. Cerkiew w Białymstoku. Budownictwo Sakralne i Monumentalne'1996. Wydawnictwa Politechniki Białostockiej, Białystok, 1996, p. 207-216.

11. PODGÓRZEC, Z. Mój Chrystus. Rozmowy z Jerzym Nowosielskim. Wydawnictwo Łuk, Białystok, 1993, p. 121-130.

\section{APIE VERTYBIŲ DIALOGĄ RYTŲ IR VAKARŲ SAKRALINĖJE ARCHITEKTŪROJE}

\section{J. Uścinowicz}

Santrauka. Analizuojama kultūrų dialogo sakralinèje architektūroje tema. Pasitelkiant istorinius ir šiuolaikinius pavyzdžius aptariamos Rytų (stačiatikių ir unitų) ir Vakarų (katalikų ir protestantų) bažnytinèje architektūroje pasireiškusios tarpusavio ittakos ir sąveikos buvusios Lenkijos Karalystès ir Lietuvos didžiosios kunigaikštystės teritorijoje. Nagrinejjamos maldos namų konfesinès konversijos, jų naudojimas ekumeninèms apeigoms, stačiatikių ikonografijos apraiškos katalikų bažnyčiose. Straipsnio autorius dalijasi krikščioniškojo meno sinteze pagrịstų meninių sprendimų taikymo patirtimi, sukaupta projektuojant maldos namus.

Reikšminiai žodžiai: architektūra, šventykla, sakralumas, konversija, adaptacija, sintezè, paribiai.

\section{JERZY UŚCINOWICZ}

PhD Eng, Arch, lecturer in the Faculty of Architecture of Biatystok University of Technology, head of Department of Public Utilities Architecture.

Projects: author and co-author of 50 projects of architectural design, including 24 sacral buildings. Honorary awards: holder of 12 prizes and distinctions. Conferences: participant with research papers at 50 international academic conferences.

\footnotetext{
* the author asks knowledge and support of the scientific research by the KBN under the rector's project W/WA/7/05
} 